\title{
Forum on Teaching: Constructing Historical Cases
}

\author{
Foy Williamson-Lott and Nancy Beadie
}

\section{Introduction}

For this first History of Education Quarterly teaching forum, we asked several scholar-teachers to address one strategy for using scholarship in the history of education in their teaching: the construction of historical cases. Case studies are often used to shed light on a contemporary educational policy or condition, disrupt commonly held historical beliefs about education by presenting counter narratives through particular cases, examine the educational development of a particular place and/or to interrogate the regional distinctiveness of educational development, or give students a sense of the dialectical nature of structure and agency that informs all aspects of educational provision. We suspect that many of us, if not all, use case studies for these and other purposes as powerful vehicles in our teaching.

We asked these scholar-teachers to reflect on the ways they use case studies in their own classrooms and to respond to the prompt: "What are they cases of? What have students learned from a case study approach? What have you learned? How is this type of knowledge important to the purposes of education in your context (i.e., professional preparation, liberal arts learning, and graduate or undergraduate historical studies)?" The following eight essays provide readers with an intimate look at how these authors employ case studies to achieve different ends. Readers will also see how these authors push their students to develop historical empathy, analyze claims and arguments, recognize historical significance in the students' own lives, challenge students' assumptions about progress, and even contribute new knowledge to local history.

The History of Education Quarterly editorial team would like to thank these scholar-teachers for the seriousness with which they took this task. As part of the Forum, they shared initial essays with each other and commented on each other's work in a shared online space before revising their essays (more than once!) in response. We greatly 
appreciate the time they put into this process and the depth of their reflections about their own and each other's work. When we teach, we often reach more broadly than we do in our scholarship. This set of essays illuminates the significance of our work in the field at a level beyond that represented in a typical academic article. Also, we wish to thank these scholar-teachers for the high-quality work they do in their classrooms. They do our history of education community proud.

\section{Defining Purpose and Process in Teaching History with Case Studies}

\section{Fack Dougherty}

Course: Education Reform, Past and Present (mid-level survey course that typically enrolls twenty undergraduates)

Course: Cities, Suburbs \& Schools (upper-level research seminar that enrolls ten to fifteen undergraduates)

Institution: Trinity College, Hartford, Connecticut ${ }^{1}$

When the History of Education Quarterly editors invited us to contribute to this forum, they asked us to reflect on how we taught history with case studies. To jump-start our exchange, they suggested four possible purposes for teaching history in this way, which I have paraphrased below:

- To reflect on the antecedents of the so-called "new" educational policy topics (what is the long history of standardized testing?).

- To disrupt conventional beliefs with counterexamples (why did nineteenth-century science and math classrooms include so many female students?).

- To compare and contrast educational change in particular places or regions (how did the development of schooling differ in New England, the New South, or New Mexico?).

Jack Dougherty is Associate Professor of Educational Studies at Trinity College, Hartford, Connecticut, where he and his students explore the history of cities, suburbs, and schools. He teaches two courses: Education Reform-Past and Present (a mid-level survey course that typically enrolls twenty undergraduates) and Cities, Suburbs, and Schools (an upper-level research seminar that enrolls ten to fifteen undergraduates). For syllabus and course materials for the former, see http://commons.trincoll.edu/edreform; for the latter's, see http://commons.trincoll.edu/cssp. 